UDC 336.27:658.15:005.3

DOI: $10.15673 /$ fie.v11i3.1457

\author{
Vaskovska K. \\ Ph.D., Associate Professor \\ Department of Accounting and Auditing \\ E-mail: v.caterin17@gmail.com \\ ORCID ID: 0000-0001-8093-170X \\ Volodina 0. \\ Assistant \\ Department of Foreign Languages \\ E-mail: completeness7@mail.ru
}

\author{
Doycheva K. \\ PhD., Assistant \\ Department of Accounting and Auditing \\ E-mail: doicheva.ks@gmail.com \\ ORCID ID: 0000-0001-5730-8899
}

\author{
Kukushkina 0. \\ Undergraduate \\ Department of Accounting and Auditing \\ Odessa National Academy of Food Technologies \\ Kanatna str., 112, Odesa, Ukraine, 65039 \\ E-mail: kukushkina.e@ukr.net
}

\title{
CREDIT INDEBTEDNESS OF THE ENTERPRISE: THEORETICAL AND PRACTICAL ASPECTS OF ANALYSIS AND MANAGEMENT
}

The article investigates the definition of the essence of the category «credit indebtedness» in terms of domestic legislation and according to domestic and foreign experts in the field of accounting. The criteria for classification of credit indebtedness by maturity have been studied, the optimal stages of management of credit indebtedness have been determined. The authors established the positive and negative consequences of the enterprise's accumulation of credit indebtedness amounts. Studying the correspondence of credit indebtedness amounts, establishing the causes of its formation and maturity, determining the turnover term, checking the existence of overdue and hopeless credit indebtedness, checking the reliability of reflecting amounts of credit indebtedness are the key points in the analysis, estimation and efficiency of management of the size of the enterprise credit indebtedness. The skillful management and maneuvering of the amounts of credit indebtedness is a defining moment in the further development of the activity and prosperity of the enterprise itself.

Keywords: enterprise, liabilities, credit indebtedness, debt classification, analysis, credit indebtedness management.

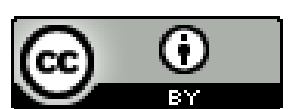

This work is licensed under a Creative Commons Attribution 4.0 International License http://creativecommons.org/licenses/by/4.0/
Statement of the problem and its connection with important scientific and practical tasks. The normal functioning of every enterprise not only in Ukraine but also in the world is daily accompanied by various calculations: with counterparties, with accountable persons, with financial institutions, with the budget and with employees. In the process of such calculations, the company receives a loan amount of funds, that is, credit indebtedness occurs.

Debt availability is normal for any business cycle. However, the prolonged financial and economic crisis in Ukraine has an impact on financial discipline. This leads to failure to comply with the terms of the contract and the current legislation and, in turn, to the negative balance of payments of many enterprises, and thus to possible preconditions for bankruptcy.

In order to achieve the optimum rate of development of the enterprise, its top management must ensure constant monitoring and evaluation of the credit indebtedness, using an individual approach depending on the planned tasks. Credit indebtedness management must ensure: compliance with the terms of the contract, a prop- er reflection in the financial statements, a stable reputation of the company in the market.

The analysis of the latest publications on the problems. Many domestic scientists are interested in the problem of this study. Scientific works cover both theoretical concepts and practical methods. Important achievements in the study of credit indebtedness have been received by such domestic scientists as F.F. Butynets, S.F. Golov, I.V. Orlov, N.M. Tkachenko, Y.S. TsalTsalko, E.V. Kolyuga, A.M. Uzhva, I.O. Koblyanskaya, O.V. Marcus, N.V. Chebanov, T.I. Efimenko, V.M. Ivakhnenko, N.M. Tkachenko, S.V. Zelenko, V.S. Mukoviz, G.O. Partin, V.V. Sopko, L.V. Kruchak, O.F. Tomchuk, A.G. Semenova, S.A. Korol, N.V. Novitskaya, O.P. Antonyuk, T.M. Stupnitskaya, N.M. Kuprina. It should be noted that a number of important issues of assessment, analysis and management of credit indebtedness are left without proper attention.

Forming of the aims of the research. The main purpose of the article is to study the essence of the category «credit indebtedness», its classification and methods of analysis in order to form an effective system of man- 
agement of the level of credit indebtedness at the enterprise.

Giving an account of the main results and their substantiation. Business activity of enterprises can not be imagined without borrowing money. Credit indebtedness as a type of loan occupies a significant place in the capital of the organization. Effective attracting and using such funds can expand production and improve the financial condition of the enterprise.
The correct definition of the nature of the category «credit indebtedness» and its subsequent correct classification helps to properly reflect the information in the accounting registers, financial and tax reports. The concept of «credit indebtedness» is often equated with the concept of «obligations». The accounting regulations (standards) give the definition of the essence of the liabilities, the economic literature gives a more complete idea of the debt to other entities (Table 1).

Table 1

Definition of «credit indebtedness» and «liabilities»*

\begin{tabular}{|c|c|}
\hline Source & Definition \\
\hline $\begin{array}{l}\text { IAS } 37 \\
\text { «Provisions, contingent } \\
\text { liabilities and nominal } \\
\text { assets» }[1]\end{array}$ & $\begin{array}{l}\text { Liability - an existing obligation of an entity that arises as a result of past } \\
\text { events and which is expected to result in the outflow of an entity's resources em- } \\
\text { bodying economic benefits. }\end{array}$ \\
\hline $\begin{array}{c}\text { Accounting standard №11 } \\
\text { «Liabilities» [2] }\end{array}$ & $\begin{array}{l}\text { Contingent liability is: } \\
\text { 1) an obligation that may arise as a result of past events and whose existence } \\
\text { will be confirmed only when one or more uncertain future events occur or are not } \\
\text { fully controlled by the entity; } \\
\text { 2) the present liability that arises from past events but is not recognized because } \\
\text { it is unlikely that resources will be used to settle the liability, or if the amount of } \\
\text { the liability cannot be determined reliably. }\end{array}$ \\
\hline $\begin{array}{l}\text { Butinets F.F., } \\
\text { Goretska L.L. [3, c. 387] }\end{array}$ & $\begin{array}{l}\text { Credit indebtedness is a form of payment for goods and services purchased in } \\
\text { the course of regular recurring transactions and used for processing (as raw ma- } \\
\text { terial) or for resale. }\end{array}$ \\
\hline Sadovska I.B. [7] & $\begin{array}{l}\text { Liabilities and payments are credit indebtedness that arise as a result of the enti- } \\
\text { ty's debt to suppliers and contractors for material values, works, services, which } \\
\text { they have received but have not paid for. }\end{array}$ \\
\hline $\begin{array}{l}\text { Stupnitskaya T. M., } \\
\text { Markova T. D., } \\
\text { Bambulak I.M., } \\
\text { Kulik N.M. [8, c. 68] }\end{array}$ & $\begin{array}{l}\text { Credit indebtedness is a financial transaction between entities in which one par- } \\
\text { ty temporarily borrows commercial money for commodity circulation and the } \\
\text { other undertakes to repay the debt within the specified period. }\end{array}$ \\
\hline Tkachenko N.M. [9, c. 683] & $\begin{array}{l}\text { Credit indebtedness is temporarily borrowed funds from the entity that are re- } \\
\text { coverable to the entity or individual. }\end{array}$ \\
\hline Tomchuk O.F. [10, c. 162] & $\begin{array}{l}\text { Credit indebtedness is a type of commercial loan, which is an important factor } \\
\text { in stabilizing of the financial condition of the enterprise. }\end{array}$ \\
\hline Tsal-Tsalko Y.S. $[11$, c. 260$]$ & $\begin{array}{l}\text { Credit indebtedness is the temporary involvement of assets in the economic ac- } \\
\text { tivity of an enterprise at the expense of temporarily free acquisition of property of } \\
\text { other entities. }\end{array}$ \\
\hline $\begin{array}{l}\text { Chabanova N.V., } \\
\text { Vasilenko Y.A. [12, c. 413] }\end{array}$ & $\begin{array}{l}\text { Credit indebtedness is a special part of an organization's assets that is subject to } \\
\text { a binding legal relationship between the organization and its creditors. }\end{array}$ \\
\hline
\end{tabular}

Based on the interpretation of the concepts and opinions of other authors, we came to the conclusion that the credit indebtedness is working capital of other market relations entities, attracted temporarily and on a free basis, for which there are liabilities to repay within certain terms, fixed by the contract or current legislation.

Failure to comply with the terms of the contract with counterparties entails the imposition of penalties on the offending company under the current legislation or under the terms of the contract.

Correct classification plays an important role in the accounting and management of credit indebtedness. Accounting standard 11 «Liabilities» [2] defines the methodological principles for the formation and accounting of information on credit indebtedness, as well as the requirements for its disclosure in the financial statements.
However, for effective analysis and management, in our opinion, the following types of credit indebtedness should be distinguished:

- credit indebtedness to suppliers (raw materials, materials, goods and other assets of the enterprise);

- credit indebtedness to contractors (works, services);

- credit indebtedness to employees (salaries, wages and salaries under civil contracts);

- credit indebtedness to budgetary funds (taxes under current legislation);

- credit indebtedness to extrabudgetary funds (fees and payments under current law);

- credit indebtedness on social insurance (single social contribution);

- credit indebtedness to customers (advances 
received, prepayments for products, goods, services); dends);

$$
\text { - credit indebtedness to shareholders (divi- }
$$

- credit indebtedness from other calculations.

These types of credit indebtedness are also classified by maturity. According to this criterion, credit indebtedness is divided into:

1) current credit indebtedness:

- credit indebtedness, whose maturity is less than 3 months;

- credit indebtedness, the maturity of which is from 3 to 6 months;
- credit indebtedness, whose maturity is more than 6 months.

2) long-term credit indebtedness, whose maturity is more than 12 months.

3) overdue credit indebtedness - not repaid within the period established by the contract.

4) hopeless credit indebtedness - the period of limitation (general -3 years, special - according to the current legislation), which expired.

Debt management at the enterprise is differentiated and occurs in several stages (Fig. 1).

Analysis of credit indebtedness in previous periods

Formation of the composition and structure of credit indebtedness of the enterprise for the future

Determining the frequency of debt repayment by individual types and creditors

Formation of the schedule of repayment of credit indebtedness

Planning and forecasting of dynamics of growth of credit indebtedness in the enterprise

Analysis and assessment of the increase in credit indebtedness in future periods

Fig. 1. Stages of management of the enterprise credit indebtedness *

* generalized by the authors themselves

The analysis of the credit indebtedness of the enterprise in previous periods includes the study of the composition, structure and dynamics of debt in the enterprise for the period, as well as an assessment of its turnover and the ratio of the amount and rate of growth of debit indebtedness at the enterprise.

The credit indebtedness turnover period is characterized by the ratio of the number of days per period and the credit indebtedness turnover ratio, which is determined by dividing the cost of sales by the average amount of credit indebtedness over the period, including arrears for goods (work, services), other current liabilities and promissory notes issued.

It should be remembered that the amount of credit indebtedness for most of its types and maturities is estimated, since it is not always possible to quantify with certainty the groups of debt due to the volatility of the market and economic activity of the enterprise in the future.

The repayment period (schedule of payments) depends first and foremost on the requirements of the current legislation and on the terms of the concluded agreements with partners, and therefore has a significant impact on the amounts owed, both by individual types and by the enterprise as a whole.

However, along with the positive effects of the formation of credit indebtedness (attracting additional working capital, reducing the risk of loss from inflation, increasing additional profit) the negative side of debt to counterparties can be noted, which is reflected in the increased risk of loss of financial equilibrium, increased amount of liabilities or increased discounts on goods, works, services. It is precisely because of the impact of a number of essential factors that liabilities management becomes so important in the context of the economic crisis and unstable political situation in Ukraine.

In order to counteract the impact of negative shifts, the enterprise's administrative staff must regularly carry out a comprehensive analysis and assessment of liabilities and plan an allowable amount of debt (Fig. 2). 
Liability analysis for identifying signs of insolvency of the enterprise, anticipating delays and preventing bankruptcy

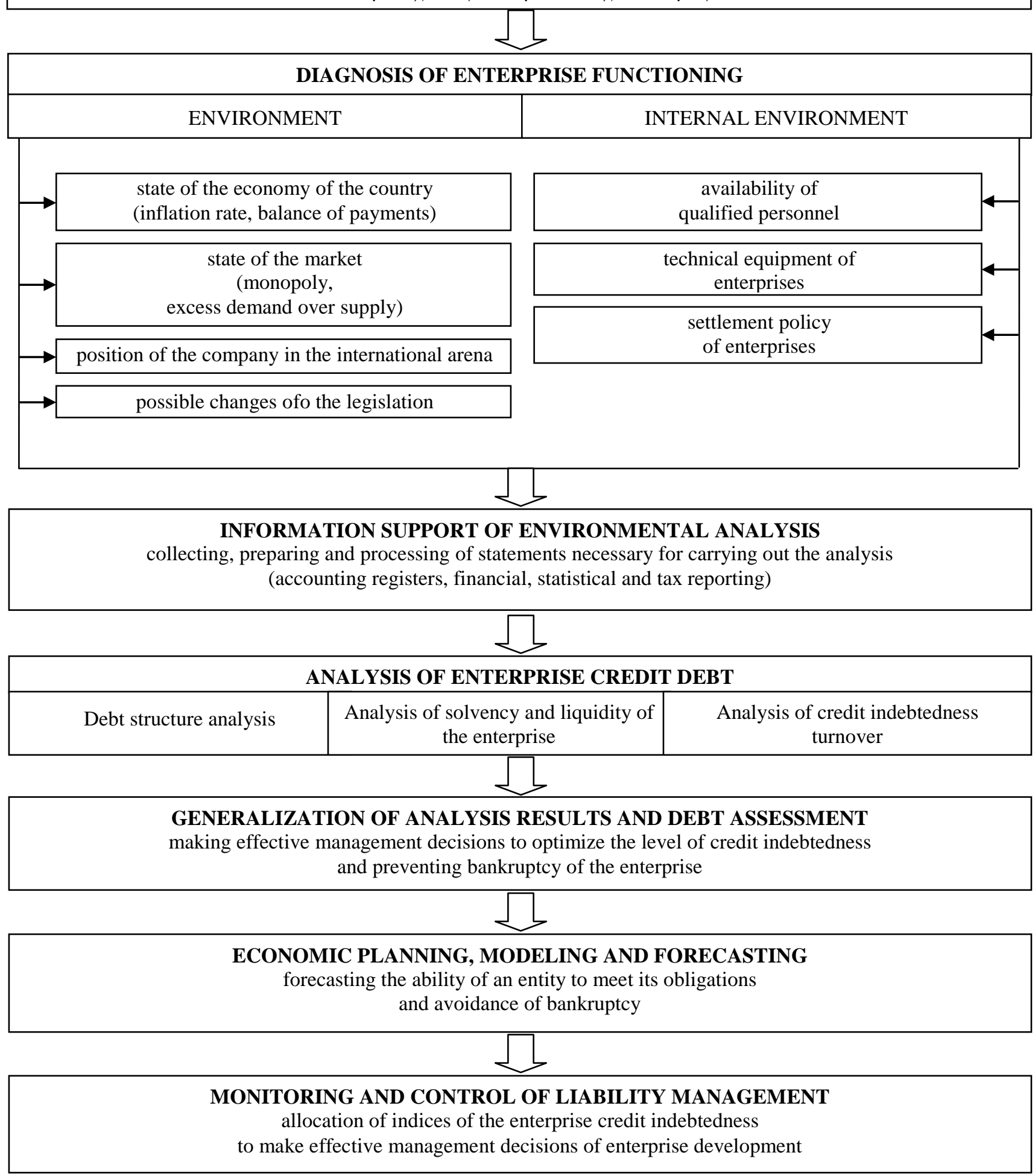

Fig. 2. Methods of analysis of credit indebtedness enterprise*

*summarized by authors based on source [6]

Conclusions and prospects of the further investigations. Credit indebtedness is interest-free lending to any business that is temporary and is the most attractive way to finance it.

The enterprise's cash income will increase if the wages are delayed to employees, or the suppliers or con- tractors are billed for the longest possible time and the maximum amount of money. However, delays can lead to a number of negative consequences, such as loss of corporate reputation, lack of further deliveries, legal cost for counterparty claims, and penalties for breaches of employee pay delay laws. 
Thus, credit indebtedness, as a form of loan capital in the course of business activity of the enterprise, has a number of features, which makes it quite attractive for the enterprise.

Thus, credit indebtedness is a free source of financing for the enterprise and provides a reduction in the size of the loan capital of the enterprise. The duration of the financial cycle of the enterprise is influenced by the amount of debt (expressed in days of turnover), which provides the required amount of funds to finance working capital, including current assets of the enterprise and determines its solvency.

In the course of the activity the direct dependence of the amount of arrears on the volume of production and sale of products is traced, since the increase in the volume of production leads to an increase in the costs of production itself, in particular the cost of purchasing additional volume of raw materials and materials, the increase in the cost of labor (in a piece-rate form of payment), etc.

Effective management of credit indebtedness begins at the time of the conclusion of an agreement to discuss all material aspects and conditions, in particular the liability of counterparties (the amount of penalties for loss of profit, the impact of inflation, etc.) for late payment of debt.

The skillful management and maneuvering of credit indebtedness is a defining moment in the further development of the business and the prosperity of the enterprise itself.

\section{References}

1. Zabezpechennia, umovni zobov'iazannia ta umovni aktyvy: Mizhnarodnyi standart bukhhalterskoho obliku №37: zatv. IASB vid 01.01.2012 r. za stanom na 30.06.2017 r. (2017). Retrieved July 26, 2019, from https://ips.ligazakon.net/document/view/MU17051.

2. Zobov'iazannia: Polozhennia (standart) bukhhalterskoho obliku 11: zatv. nakazom Minfinu vid 31.01.2000 r. № 20 za stanom na 08.02.2014 r. (2014). Retrieved July 24, 2018, from https://zakon.rada.gov.ua/laws/show/z008500 .

3. Butynets, F. F., \& Horetska, L. L. (2003). Bukhhalterskyi oblik u zarubizhnykh krainakh. Zhytomyr: Ruta.

4. Honcharuk, R. P. (2015). Sutnist ta klasyfikatsiia kredytorskoi zaborhovanosti: kolizii naukovykh pidkhodiv. Visnyk Zhytomyrskoho Derzhavnoho Tekhnolohichnoho Universytetu, (1 (59), Ch. 1), 48-51.

5. Novytska, N. V. (2012). Teoretychni aspekty poniat «debitorska zaborhovanist» i «kredytorska zaborhovanist». Aktualni Problemy Ekonomiky, (2), 286-290.

6. Harasym, P. M., Harasym, M. P., \& Lobod, N. O. (2014). Strukturna dynamika zobov'iazan pidpryiemstva yak klasychna oblikovo-analitychna paradyhma. Ekonomichni Nauky, (11 (41), Ch. 2 ), 108.

7. Sadovska, I. B., Bozhydarnik, T. V., \& Nahirska, K. Ye. (2013). Bukhhalterskyi oblik. Kyiv: «Tsentr uchbovoi literatury»).

8. Stupnytska, T. M. (2018). Kredytorska zaborhovanist: otsinka ta mekhanizmy upravlinnia. Ekonomika Kharchovoi Promyslovosti, 10(4), 66-78. doi: 10.15673/fie.v10i4.1134

9. Tkachenko, N. M. (2013). Bukhhalterskyi finansovyi oblik, opodatkuvannia i zvitnist (6 (dopov. i pererob.)). Kyiv: Alerta.

10. Tomchuk, O. F. (2018). Analitychne zabezpechennia upravlinnia kredytorskoiu zaborhovanistiu pidpryiemstva. Naukovyi Visnyk Lvivskoho Natsionalnoho Universytetu Veterynarnoi Medytsyny Ta Biotekhnolohii Imeni S.Z. Gzhytskoho, (2 (69), 160-164. doi: 10.15421/nvlvet6931

11. Tsal-Tsalko, Yu. S. (2008). Finansovyi analiz. Kyiv: Tsentr uchbovoi literatury.

12. Chebanova, N. V., \& Vasylenko, Yu. A. (2002). Bukhhalterskyi finansovyi oblik. Kyiv: Vydavnychyi tsentr «Akademiia».

Received 5 August2019

Approved 19 August 2019

Available in Internet 16.10.2019

Васьковская E.A.

кандидат экономических наук, доцент кафредра учета и аудита

E-mail: v.caterin17@gmail.com

ORCID ID: 0000-0001-8093-170X

\section{Володина Е.П.} ассистент

кафедра иностранных языков

E-mail: completeness7@mail.ru
Дойчева К.С.

кандидат экономических наук, старший преподаватель кафредра учета и аудита E-mail: doicheva.ks@gmail.com ORCID ID: 0000-0001-5730-8899

Кукушкина Е.A. магистрант

Одесская национальная академия пищевых технологий ул. Канатная, 112, г. Одесса, Украина, 65039

E-mail: kukushkina.e@ukr.net

\section{КРЕДИТОРСКАЯ ЗАДОЛЖЕННОСТЬ ПРЕДПРИЯТИЯ: ТЕОРЕТИЧЕСКИЕ И ПРАКТИЧЕСКИЕ АСПЕКТЫ АНАЛИЗА И УПРАВЛЕНИЯ}

В статье изучены определения сущности категории «кредиторская задолженность» с точки зрения отечественного законодательства и, по мнению отечественных и иностранных специалистов, 
в области бухгалтерского учета.

Изучены критерии классификации кредиторской задолженности по срокам погашения, определены оптимальные этапы управления кредиторской задолженностью.

Перечислены основные показатели для анализа состояния кредиторской задолженности. Авторы публикации пришли к выводу, что исследование динамики кредиторской задолженности, планирование ее прироста относительно прошлых периодов, соблюдение своевременного погашения и контроль за оптимальным соотношением дебиторской и кредиторской задолженности позволяют успешно использовать ошибки административного персонала для их дальнейшего недопущения.

Авторами установлены позитивные и негативные последствия накопления предприятием сумм кредиторской задолженности.

Изучение соответствия сумм кредиторской задолженности, установления причин ее образования и сроков погашения, определение срока оборачиваемости, проверка наличия просроченной и безнадежной кредиторской задолженности, проверка достоверности отражения сумм кредиторской задолженности (по соответствующим статьям пассива баланса предприятия) являются ключевыми моментами в анализе, оценке и эффективности управления размерами кредиторской задолженности предприятия.

Согласно неоднородности кредиторской задолженности по видам и степени влияния на деятельность предприятия авторами предложена ее классификация для эффективного управления, а также методика анализа кредиторской задолженности относительно размеров и сроков погашения.

В результате исследования были сделаны выводы о том, что управление кредиторской задолженностью начинается с момента заключения договора, в котором прописываются ответственности сторон, и до признания предприятия банкротом. Умелое управление и маневрирование размерами кредиторской задолженности является определяющим моментом в дальнейшем развитии деятельности и процветания самого предприятия.

Ключевые слова: предприятие, обязательства, кредиторская задолженность, классификация задолженности, анализ, управление кредиторской задолженностью.

Васьковська К.О.

кандидат економічних наук, доцент кафедра обліку та аудиту

E-mail: v.caterin17@gmail.com

ORCID ID: 0000-0001-8093-170X

Володіна О.п. асистент

кафедра іноземних мов

E-mail: completeness7@mail.ru
Дойчева К.С.

кандидат економічних наук, старший викладач кафедра обліку та аудиту E-mail: doicheva.ks@gmail.com ORCID ID: 0000-0001-5730-8899

Кукушкіна О.O. магістрант

Одеська національна академія харчових технологій вул. Канатна, 112, м. Одеса, Україна, 65039

E-mail: kukushkina.e@ukr.net

\section{КРЕДИТОРСЬКА ЗАБОРГОВАНІСТЬ ПІДПРИЕМСТВА: ТЕОРЕТИЧНІ ТА ПРАКТИЧНІ АСПЕКТИ АНАЛІЗУ ТА УПРАВЛІННЯ}

У статті досліджені визначення сутності категорії «кредиторська заборгованість» 3 точки зору вітчизняного законодавства і на думку вітчизняних і закордонних фахівців в області бухгалтерського обліку.

Вивчено критерії класифікації кредиторської заборгованості за термінами погашення, визначені оптимальні етапи управління кредиторською заборгованістю.

Перераховано основні показники для аналізу стану кредиторської заборгованості. Автори публікації прийшли до висновку, що дослідження динаміки кредиторської заборгованості, планування її приросту щодо минулих періодів, дотримання своєчасного погашення та контроль за оптимальним співвідношенням дебіторської і кредиторської заборгованості дозволяють успішно використовувати помилки адміністративного персоналу для їх подальшого недопущення.

Авторами встановлені позитивні і негативні наслідки накопичення підприємством сум кредиторської заборгованості.

Вивчення відповідності сум кредиторської заборгованості, встановлення причин її утворення і термінів погашення, визначення терміну оборотності, перевірка наявності простроченої та безнадійної кредиторської заборгованості, перевірка достовірності відображення сум кредиторської заборгованості (за відповідними статтями пасиву балансу підприємства) є ключовими моментами в аналізі, оцінці та ефективності управління розмірами кредиторської заборгованості підприємства. 
Згідно неоднорідності кредиторської заборгованості за видами і ступенем впливу на діяльність підприємства авторами запропонована її класифікація для ефективного управління, а також методика аналізу кредиторської заборгованості щодо розмірів і термінів погашення.

У результаті дослідження були зроблені висновки про те, що управління кредиторською заборгованістю починається з моменту укладення договору, в якому прописуються відповідальності сторін, і до визнання підприємства банкрутом. Вміле управління і маневрування розмірами кредиторської заборгованості $€$ визначальним моментом в подальшому розвитку діяльності і процвітання самого підприємства.

Ключові слова: підприємство, зобов'язання, кредиторська заборгованість, класифікація заборгованості, аналіз, управління кредиторською заборгованістю.

\section{Література}

1. Забезпечення, умовні зобов'язання та умовні активи: Міжнародний стандарт бухгалтерського обліку №37: затв. IASB від 01.01 .2012 p. за станом на 30.06 .2017 p. URL: https://ips.ligazakon.net/document/view/MU17051 (дата звернення: 26.07.2019).

2. Зобов'язання: Положення (стандарт) бухгалтерського обліку 11: затв. наказом Мінфіну від 31.01.2000 р. № 20 за станом на 08.02.2014 p. URL: https://zakon.rada.gov.ua/laws/show/z0085-00 (дата звернення: 24.07.2018)

3. Бутинець Ф.Ф., Горецька Л.Л. Бухгалтерський облік у зарубіжних країнах. Житомир: Рута, 2003. $544 \mathrm{c}$.

4. Гончарук Р.П. Сутність та класифікація кредиторської заборгованості: колізії наукових підходів // Вісник Житомирського державного технологічного університету. Сер. Економічні науки. 2015. №. 1(59), Ч. 1. 48-51.

5. Новицька Н.В. Теоретичні аспекти понять «дебіторська заборгованість» і «кредиторська заборгованість» // Актуальні проблеми економіки. 2012. №. 2. С. 286-290.

6. Гарасим П.М., Гарасим М.П., Лобод Н.О. Структурна динаміка зобов'язань підприємства як класична обліковоаналітична парадигма // Економічні науки. Сер. Облік і фінанси. Вип. 11(41). Ч. 2. 2014. С. 108.

7. Садовська І. Б., Божидарнік Т. В., Нагірська К. Є. Бухгалтерський облік: навч. посіб. К.: «Центр учбової літератури», 2013. 44 с.

8. Кредиторська заборгованість: оцінка та механізми управління / Ступницька Т.М. та ін. // Економіка харчової промисловості, 2018. Т. 10, вип. 4. С. 66-78. doi: 10.15673/fie.v10i4.1134.

9. Ткаченко Н.М. Бухгалтерський фінансовий облік, оподаткування і звітність: підручник. 6-те вид. допов. і перероб. К.: Алерта, 2013. 982 с.

10. Томчук О.Ф. Аналітичне забезпечення управління кредиторською заборгованістю підприємства // Науковий вісник Львівського національного університету ветеринарної медицини та біотехнологій імені С.3. Гжицького, 2018, № 2 (69), С. 160-164. doi: 10.15421/nvlvet6931

11. Цал-Цалко Ю.С. Фінансовий аналіз. К.: Центр учбової літератури, 2008. 260 с.

12. Чебанова Н. В., Василенко Ю. А. Бухгалтерський фінансовий облік: посіб. Київ: Видавничий центр «Академія», 2002. 672 с.

Стаття надійшла 5.08.2019

Стаття прийнята до друку 19.08.2019

Доступно в мережі Internet 16.10.2019

Цитування згідно ДСТУ 8302:2015

Vaskovska K., Doycheva K., Volodina O., Kukushkina O. Credit indebtedness of the enterprise: theoretical and practical aspects of analysis and management // Food Industry Economics. 2019. Vol.11, Issue 3. P. 16-22. doi: 10.15673/fie.v11i3.1457

Cite as APA style citation

Vaskovska, K., Doycheva, K., Volodina, O., \& Kukushkina, O. (2019). Credit indebtedness of the enterprise: theoretical and practical aspects of analysis and management. Food Industry Economics, 11(3), 16-22. doi: 10.15673/fie.v11i3.1457 